\title{
ANALISIS TEOLOGIS TANGGUNG JAWAB ORANG TUA KRISTEN DALAM PENDAMPINGAN PEMBELAJARAN DARING TERHADAP PENGARUH GADGET BAGI PERKEMBANGAN KOGNITIF ANAK USIA 7-11 TAHUN
}

\author{
Jonidius Illu, Djulius Thomas Bilo, Yublina Kasse \\ Sekolah Tinggi Teologi Injili Arastamar (SETIA) Jakarta \\ joni.illu@gmail.com
}

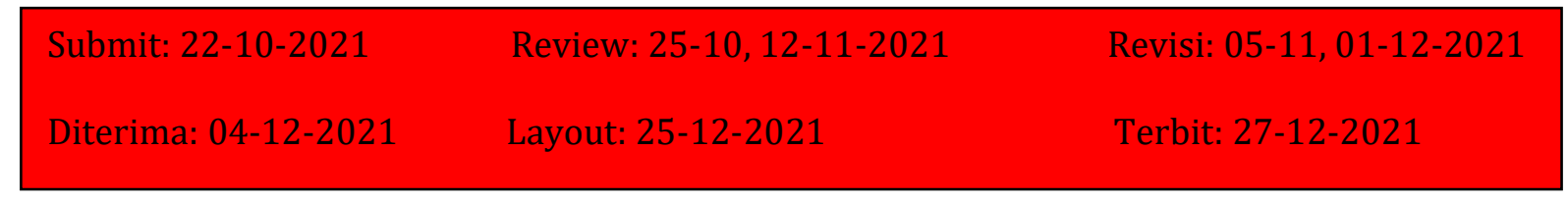

\begin{abstract}
Cognitive development is influenced by the environment including gadgets so that if children use gadgets excessively it can affect cognitive development. That is why the use of gadgets during online learning if used properly and effectively then gadgets is useful in improving children's cognitive and vice versa, if gadgets are used during online learning with a purpose that is not in the portion of online learning it will interfere with cognitive development which can have an impact on children's lives. One of the problems that have an impact on children's cognitive is the online learning factor. Because many children do not use time effectively during online learning. Cognitive development has been influenced by gadgets. This problem is caused by online games that appear during online learning, unattractive presentation of material from a teacher, boredom of children during online learning and the amount of ineffective time during online learning as a result, children spend a lot of time playing gadgets. For almost two years (2019-2021), there are parents who have difficulty controlling the gadgets used by their children, so through this article it is hoped that they can find out whether the influence of gadgets on online learning on the cognitive development of children aged 7-11 years, both positive and negative impacts negative The method in this writing is qualitative, meaning that by using library research, namely collecting data from various sources to obtain information in order to find appropriate information to be usedThe purpose of this paper is to obtain information related to the influence of gadgets on online learning on the cognitive development of children aged 7-11 yearsSo it can be concluded that this research is necessary because of the wrong use of gadgets during online learning. This is where the role of parents in providing assistance so that children use good gadgets so as not to have a bad impact on children's cognitive development.
\end{abstract}

Keywords: theological analysis, parental responsibility, online learning, gadgets, cognitive development, children aged 7-11 years.

\section{Abstrak}

Perkembangan kognitif dipengaruhi oleh lingkungan termasuk di dalamnya adalah gadget sehingga jika anak penggunaan gadget yang berlebihan bisa memengaruhi perkembangan kognitif. Itu sebabnya penggunaan gadget selama pembelajaran daring jika digunakan dengan benar dan efektif maka gadget berguna dalam meningkatkan kognitif anak juga sebaliknya, jika gadget digunakan selama pembelajaran daring dengan tujuan yang bukan pada porsi pembelajaran daring maka akan mengganggu perkembangan kognitif yang dapat berdampak pada kehidupan anak. Salah satu problem yang berdampak pada kognitif anak adalah faktor pembelajaran daring. Oleh 
ANALISIS TEOLOGIS TANGGUNG JAWAB ORANG TUA ... (Jonidius Illu, Dyulius Thomas Bilo, Yublina Kasse)

karena banyak anak yang tidak menggunakan waktu yang efektif selama pembelajaran daring. Perkembangan kognitif telah dipengaruhi oleh gadged. Problem ini disebabkan oleh games online yang muncul saat pembelajaran daring, penyajian materi yang tidak menarik dari seorang guru, kejenuhan anak selama pembelajaran daring dan banyaknya waktu yang tidak efektif selama pembelajaran daring akibatnya banyak waktu yang dipakai anak untuk bermain gadget. Hampir selama dua tahun ini (2019-2021), ada orang tua yang mengalami kesulitan mengontrol gadget yang digunakan anak, sehingga melalui tulisan ini diharapkan dapat mengetahui apakah pengaruh gadget pada pembelajaran daring terhadap perkembangan kognitif anak usia 7-11 tahun, baik dampak positif atau dampak negatif. Metode dalam penulisan ini adalah kualitatif artinya dengan menggunakan penelitian kepustakaan yaitu mengumpulkan data dari berbagai sumber untuk mendapatkan informasi guna menemukan informasi yang sesuai untuk dipergunakan. Tujuan dari tulisan ini, diharapkan agar dapat memperoleh informasi terkait pengaruh gadget pada pembelajaran daring terhadap perkebangan kognitif anak usia 7-11 tahun. Jadi dapat disimpulkan bahwa penelitian ini perlu karena penggunaan gadget yang salah selama pembelajaran daring. Di sinilah peran orang tua dalam melakukan pendampingan sehingga anak menggunakan gadget yang baik agar tidak berdampak buruk pada perkembangan kognitif anak.

Kata kunci: analisis teologis, tanggung jawab orang tua, pembelajaran daring, gadget, perkembangan kognitif, anak usia 7-11 tahun

\section{Pendahuluan}

Tulisan ini sangat berbeda dengan tulisan yang ditulis oleh Overianus Halawa dan Menase Gulo. ${ }^{1}$ Kedua penulis lebih menekankan tentang peran orang tua selama melakukan pendampingan pembelajaran daring, sementara penulis lebih menekankan dampak dari gadget bagi kognitif anak dan peran orang tua dalam melakukan pendampingan selama pembelajaran daring.

Anak adalah karunia Allah yang dipercayakan kepada sebuah keluarga untuk dididik, diajar, agar bertumbuh menjadi dewasa dan menjadi pribadi yang memiliki kehidupan yang sehat dalam berbagai aspek termasuk perkembangan kognitif yang sehat. E. B. Surbakti berkata, "Mendidik dan mengajar anak-anak anda supaya memiliki kecerdasan intelektual dan keterampilan adalah kewajiban Anda sebagai orang tua yang bertanggung jawab." 2 Ini memberikan pengertian bahwa orang tua memiliki peranan penting dalam pembentukan kognitif anak.

Untuk mencapai tujuan tersebut di atas, maka orang tua bertanggung jawab dalam memikirkan dan melakukan langkah yang tepat dalam memberikan pendampingan selama pembelajaran daring sehingga anak memiliki perkembangan kognitif yang sehat. Pendapat ini ditegaskan oleh Yakub B, Susabda bahwa, "Anak-anak adalah milik Allah, kita sebagai rekan-rekan kerja Allah (1Kor. 6:1) terpanggil untuk mempertanggungjawabkan setiap tindakan pelayanan kita. Allah tidak pernah membiarkan kita dibebani lebih dari kekuatan kita (1Kor. 10:13b), oleh sebab itu, perlu

1Overianus Halawa dan Menase Gulo, Kajian Teologis Pendampingan Orang tua Terhadap Anak Dalam Belajar Dimasa Pandemik coronaviruses disease 2019 (Bengkulu: Manna Rafflesia, Vol. 8, No. 1, Oktober 2021, (154-175).

2E. B. Surbekti, Parenting Anak-Anak (Jakarta: Gramedia, 2012), 153. 
merencanakan "keluarga" dalam jangkauan kemampuan pertanggungjawaban sebagai orang tua. Dengan itulah orang tua mendidik dan mempersiapkan "anak-anak Allah" yang dipercayakan Allah kepada mereka untuk "mewarisi dan mengerjakan" ciptaan Allah. ${ }^{3}$

Dengan memperhatikan perkembangan dunia yang masuk pada era post-modern, tidak dapat dipungkiri bahwa anak bisa terbawa arus dengan berbagai perubahan yang terjadi sekarang, jika tidak dibentengi dengan pengajaran yang benar terutama Firman Tuhan diajarkan secara berulang-ulang (bdk. Ul. 6:4-9), sebab Firman Tuhan menjelaskan bahwa manusia jatuh dalam dosa karena dua hal yaitu keinginan manusia yang tidak bisa dikontrol oleh diri sendiri yang berbuahkan dosa (bdk. Yak. 1:13-14). Pencobaan berasal dari diri sendiri dan terus-menerus ada dengan berbagai macam cara duniawi yang bisa menyeret manusia untuk mengikutinya termasuk penggunaan gadget yang disalahgunakan. ${ }^{4}$ Selain itu, Iblis dengan berbagai tipu muslihatnya untuk menjerumuskan manusia dalam melakukan keinginannya (bdk. 1Pet. 5:8). Iblis perlu diwaspadai dan dihadapi dengan segala kewaspadaan dan kesadaran akan eksistensinya karena ia digambarkan seperti binatang buas yang berbahaya (1Ptr. 5:8), monster yang melawan siapa saja, yang berkeliaran ke mana saja, dan yang membuat dunia ini tidak nyaman oleh karena memberikan tawaran-tawaran dunia yang kelihatannya memberikan kenyamanan tetapi dapat menghancurkan hidup manusia seperti yang pernah dialami oleh Adam dan Hawa (Kej. 3:6). ${ }^{5}$ Salah satu kejahatan yang terjadi dalam dunia digital yang bisa memengaruhi perkembangan kognitif anak, yang merusak masa depan anak, misalnya games yang menggandung konten kekerasan juga keluhan dari orang tua yang menemukan anaknya melihat gambar porno. ${ }^{6}$ Dunia maya menyediakan berbagai informasi yang jika tidak disharing akan merusak pola pikir dan perkembangan mental yang berdampak pada masa kini dan masa depan seseorang, termasuk anak pengguna gadget.

Selain penggunaan gadget secara negatif yang dijelaskan di atas, juga ada gadget digunakan oleh anak usia 7-11 tahun dalam penggunaan yang positif, misalnya memudahkan anak dalam berkomunikasi dengan guru, dan teman sekelas selama pembelajaran daring.

Anak pada usia 7-11 tahun tergolong dalam usia sekolah. Ada berbagai aspek perkembangan yang dialami oleh anak pada umumnya di antaranya ada dasar-dasar yang penting dari perkembangan kognitif, sehingga bagaimana menanamkan normanorma yang sesusai iman Kristen melalui teknik kedisiplinan dalam proses pembelajaran daring. ${ }^{7}$ Adanya faktor-faktor yang diangap penting dibangun bagi perkembangan kognitif sehingga anak bertumbuh dan berkembang secara berkualitas karena memiliki cara berpikir yang benar. Pembelajaran secara daring merupakan sebuah model belajar yang sedang terjadi memiliki dampak bagi perkembangan kognitif belajar anak di rumah dan ini menurut Pieget sebagai sebuah interaksi dengan

${ }^{3}$ Yakub B. Susabda, Pembinaan Keluarga Kristen (Bandung: Pionir Jaya, 2010), 2.

${ }^{4}$ Hiskia Gulo, Konsep Pencobaan Menurut Yakobus 1:12-15 (Purwokerto: Bonafide - Jurnal Teologi dan Pendidikan Kristen, 2020), vol. 1, No. 2, 171.

5Jonidius Illu, Pengusiran Setan: Sinkronisasi Iman, Kekudusan Hidup, Doa, dan Pengetahuan Alkitab, Phronesis: Jurnal Teologi dan Misi, vol. 2 No. 2, Desember 2020, 171.

${ }^{6}$ Menurut Yakub B. Susabda dkk., hal ini biasanya terjadi karena iseng, ingin tahu, tidak konsisten dalam disiplin. Yakub B. Susabda dkk., Pelayanan Konseling Melalui Telepon (Yogyakarta: ANDI, 2010 ), 95.

${ }^{7}$ Alkitab penuh dengan kesaksian panggilan Allah untuk mengasihi, mendidik, mengajarkan Firman Tuhan dan mendisiplinkan anak-anak di dalam kebenaran Allah. Yakub B. Susabda, Pembinaan Keluarga Kristen, 132. 
ANALISIS TEOLOGIS TANGGUNG JAWAB ORANG TUA ... (Jonidius Illu, Dyulius Thomas Bilo, Yublina Kasse)

lingkungan dan objek serta kejadian-kejadian sekitarnya. 8 Dalam psikologi perkembangan banyak dibicarakan bahwa dasar kepribadian seseorang terbentuk pada masa kanak-kanak. Proses-proses perkembangan yang terjadi dalam diri seorang anak ditambah dengan apa yang dialami dan diterima selama masa kanak-kanaknya secara sedikit demi sedikit memungkinkan ia tumbuh dan berkembang menjadi manusia dewasa. ${ }^{9}$

Menurut Jean Pieget, perubahan proses berpikir anak yang akan menghasilkan pertumbuhan dalam kemampuan untuk memperoleh dan menggunakan pengetahuan anak. Kognitif anak dipengaruhi oleh dunia informasi dan komunikasi, permainan, eksplorasi, melalui gadget saat ini. Oleh sebab itu perkembangan kognitif anak bisa dipengaruhi oleh gadget jika tidak digunakan dalam porsi yang benar.

\section{Metode Penelitian}

Metode yang digunakan dalam penulisan artikel ini adalah kualitatif. ${ }^{10}$ Metode ini bermaksud menemukan informasi yang utuh agar mengetahui terjadinya dampak buruk bagi perkembangan kognitif anak yang dipengaruhi oleh perkembangan informasi yang semakin pesat melalui gadget sehingga orang tua Kristen mengetahui cara yang tepat dalam mendamping anak selama pembelajaran daring pada masa pandemi covid 19. Penelitian ini bersifat deskriptif yang menjelaskan dampak dari penggunaan gadget. Sumber data diperoleh diperoleh melalui studi kepustakaan yang berkaitan dengan topik tersebuat, kemudian diuraikan oleh penulis guna memberikan informasi yang baik tentang topik artikel tersebut yang bertujuan memberikan manfaat bagi orang tua Kristen juga bagi anak usia 7-11 tahun.

\section{Pembahasan}

Pada bagian ini, penulis menjelaskan pengertian gadget, tujuan penggunaan gadget, aturan-aturan dalam penggunaan gadget, pembelajaran daring, perkembangan kognitif anak usia 7-11 tahun, pengaruh gadget pada pembelajaran daring terhadap perkembangan kognitif anak usia 7-11 tahun dan analisis teologis tanggung jawab orang tua Kristen dalam pendampingan pembelajaran daring.

\section{A. Gadget}

Gadget adalah seperangkat alat elektronik dengan berbagai macam kegunaan, diantara untuk berkomunikasi, membantu memudahkan pekerjaan manusia dengan fungsi praktis. Perkembangan teknologi berdampak pada penggunaan gadget, yang secara praktis dan mempercepat dalam berkomunikasi dan bekerja. ${ }^{11} \mathrm{Di}$ sisi lain, gadget

\footnotetext{
${ }^{8}$ Mukhlisah A., Perkembangan Kognitif Jean Pieget dan Peningkatan Belajar Anak Diskalkulia," Pendidikan Islam, 2015.

${ }^{9}$ Singgih D. Gunarsah dan Yulia Singgih Gunarsa, Psikologi Perkembangan Anak dan Remaja (Jakarta: Libri, 2011), 3.

10Wahidmurni, Pemaparan Metode Penelitian Kualitatif, Repositori Universitas Islam Negeri Maulana Malik Ibrahim (2017).

${ }^{11}$ Gadget adalah sebuah istilah yang berasal dari Bahasa Inggris yang merujuk pada perangkat elektronik kecil yang memiliki fungsi khusus untuk mengunduh informasi-informasi terbaru dengan berbagai teknologi maupun fitur terbaru, sehingga membuat hidup manusia lebih praktis. Gadget yang memiliki akses yang tak terbatas dapat memberikan sumbangsih positif terhadap wawasan dan
} 
bisa menjadi masalah karena tidak menggunakan sesuai dengan fungsinya. Menurut Wahyuni, teknologi telah menyediakan jenis fasilitas di dunia yang saat ini membuat dunia seperti dunia maya. Salah satu teknologi yang saat ini digunakan oleh manusia adalah gadget.

Jadi gadget memiliki fungsi yang memudahkan manusia dalam melakukan berbagai kegiatan di era modern.

\section{B. Tujuan Penggunaan Gadget}

Gadget memiliki berbagai kegunaan, di antara untuk berkomunikasi, membantu memudahkan pekerjaan manusia dengan fungsi praktis. Perkembangan teknologi berdampak pada penggunaan gadget, yang secara praktis dan mempercepat dalam berkomunikasi dan bekerja, misalnya mengirimkan email, chatting sebagai pengganti SMS, browsing internet dengan mudah, menelepon gratis lewat layanan program telepon tak berbayar, bergaul di dunia maya (media sosial), menyalurkan hobi selfie, mengadakan teleconference, menonton dan bertukar film, mengadakan transaksi perbankan dan menggunakan peta dan petunjuk jalan di_smartphone. ${ }^{12}$ Di sisi lain, gadget bisa menjadi masalah karena tidak digunakan sesuai dengan fungsinya. Menurut Wahyuni, teknologi telah menyediakan jenis fasilitas di dunia yang saat ini membuat dunia seperti dunia maya. Salah satu teknologi yang saat ini digunakan oleh manusia adalah gadget karena demikian berkembangnya fitur-fitur gadget banyak orang yang tidak bisa lepas dari perangkat ini bahkan umumnya anak-anak dan remaja menggunakan gadget secara berlebihan. ${ }^{13}$

\section{Aturan-aturan dalam penggunaan gadget}

Jika dilihat dari perkembangan dunia gadget, maka tidak dapat dipungkiri bahwa kemajuan gadget sangat pesat dan tidak dapat dihindari dalam penggunaan. Perkembangan dapat dilihat sebagai sesuatu yang berguna dalam kelangsungan hidup manusia karena dapat memudahkan manusia dalam membangun komunikasi. Menurut Jimmy Pardede, "setiap perkembangan teknologi sebagai sesuatu yang harus didominasi oleh Tuhan. Perkembangan apa pun, seperti kemajuan teknologi atau internet, kita lihat sebagai suatu bentuk dominasi manusia terhadap seluruh ciptaan yang adalah milik Tuhan tetapi kadang ditunggangi Iblis. Sejak awal penciptaan, Allah memberikan manusia tugas dan kemampuan untuk menaklukan bumi, mengembangkan segala potensi yang ada dan tetap mampu untuk membuat hidup lebih limpah, lebih efesien, tetapi sayangnya manusia sering salah arah." 14 Dari pemaparan Jimmy Pardede di atas, maka peran orang tua Kristen penting dalam memberikan aturan-aturan dalam penggunaan gadget bagi anak yang mengikuti pembelajaran daring, misalnya anak tidak diizinkan bermain game online selama jam belajar. Hal ini bertujuan agar anak fokus pada pembelajaran yang berdampak pada perkembangan kognitif anak.

pengetahuan anak, baik yang bersifat akademik maupun non akademik. Lihat Susilawati, Kadek Dwinita Viandari dan Kadek Pande Ary, Peran Pola Asuh Orangtua dan Penggunaan Gadget terhadap interaksi Sosial Anak Prasekolah, Jurnal Udayana, 2019, 78-87.

12Daniel Ronda, Pengantar Konseling Pastoral (Bandung: Kalam Hidup, 2015), 208-211.

${ }^{13}$ Siahaan FB Wahyuni AS, Hubungan Lama Bermain Gadget Dengan Kondisi Mental Emosional Siswa Sekolah Dasar, Ilmu Kedokteran Makedonia Akses Terbuka (2019).

14Jimmy Pardede, Hikmat Bagi Para Ayah dan Ibu (Surabaya: Momentum, 2021), 150. 
ANALISIS TEOLOGIS TANGGUNG JAWAB ORANG TUA ... (Jonidius Illu, Dyulius Thomas Bilo, Yublina Kasse)

Aturan-aturan itu menjadi tanggung jawab orang tua Kristen dalam memberikan pencegahan bagi anak agar terhindari dari penggunaan gadget yang merusak kognitif anak. Menurut Indian Sunita, dan Eva Mayasari, aturan-aturan itu antara lain: a) beri batasan waktu menggunakan gadget. Dengan memberi batasan atau mengurangi waktu untuk menggunakan gadget maka lama kelamaan anak akan mulai lupa dengan gadgetnya; b) Kembangkan bakat anak, entah itu bermain musik, menggambar atau melukis, dan yang lainnya; c) Sering-seringlah bermain dengan anak. Orang tua yang sering bermain dengan anaknya akan membuat sang anak lebih fokus kepada orang tuanya dibanding dengan gadgetnya; d) Ajaklah anak bermain di luar rumah. Ini akan mempercepat tumbuh kembang anak, dan ajaklah ikut beraktivitas, misalnya ketika memasak, merapikan rumah, berkebun maka ajaklah anak dan aktivitas-aktivitas lain yang memungkinkan anak untuk diikutsertakan; e) Ajaklah anak rekreasi dan berolahraga. Dengan berekreasi pikiran anak akan fresh, senang, lupa dengan dengan gadgetnya. Mengajak anak berekreasi ke tempat-tempat yang memiliki pemandangan yang bagus, seperti pegunungan, pantai, kebun binatang dan yang lainnya atau sekadar bermain diteras rumah. 15

Orang tua perlu hikmat Tuhan dalam membesarkan dan mendidik anak termasuk dalam pendampingan penggunaan gadget sehingga anak bertumbuh sehat demi kemuliaan nama-Nya.

\section{Pembelajaran daring}

Pembelajaran daring adalah suatu bentuk kegiatan pembelajaran yang dilakukan secara online. Pembelajaran ini dilakukan karena anak berhak mengikuti pendidikan demi kelangsungan kehidupan dan mencerdaskan kehidupan bangsa. Anak mengikuti pendidikan agar ia memiliki perubahan perilaku sehingga kelak mampu bersosialisasi karena anak mengetahui peraturan-peraturan dan peran-peran dari masyarakat sekelilingnya agar anak dapat menjadi anggota masyarakat yang berfungsi dengan baik dan mampu berkontribusi. ${ }^{16}$

Pembelajaran daring adalah suatu pembelajaran yang dilakukan oleh sekolah dikarenakan adanya wabah virus corona yang mengharuskan untuk menjaga jarak dan mengurangi mobilitas termasuk di dalamnya proses belajar mengajar dilakukan secara jarak jauh. Pembelajaran daring menggunakan zoom, google class room, dan untuk memastikan kehadiran anak selama pembelajaran daring menggunakan whatsapp group. Selain itu, guru-guru dapat memberikan kesempatan kepada anak untuk bertanya baik lewat chat atau video call.

Dengan adanya virus COVID-19 di Indonesia saat ini berdampak bagi seluruh masyarakat. Menurut kompas, 28/03/2020 dampak virus COVID-19 terjadi di berbagai bidang seperti sosial, ekonomi, pariwisata dan pendidikan. Surat Edaran (SE) yang dikeluarkan pemerintah pada 18 Maret 2020 segala kegiatan di dalam dan di luar ruangan di semua sektor sementara waktu ditunda demi mengurangi penyebaran corona terutama pada bidang pendidikan. Pada tanggal 24 maret 2020 Menteri Pendidikan dan Kebudayaan Republik Indonesia mengeluarkan Surat Edaran Nomor 4 Tahun 2020 Tentang Pelaksanaan Kebijakan Pendidikan Dalam Masa Darurat Penyebaran COVID, dalam Surat Edaran tersebut dijelaskan bahwa proses belajar

15Indian Sunita, dan Eva Mayasari, Pengawasan Orangtua terhadap Dampak Penggunaan Gadget pada Anak, Jurnal Endurance 3 (3) Oktober 2018, 510-514.

${ }^{16}$ Nicholas P. Wolterstorff, Mendidik Untuk Kehidupan, terj. Lana Asali, cet. Ke-2 (Surabaya: Momentum, 2010), 116. 
dilaksanakan di rumah melalui pembelajaran daring atau jarak jauh dilaksanakan untuk memberikan pengalaman belajar yang bermakna bagi siswa. Belajar di rumah dapat difokuskan pada pendidikan kecakapan hidup antara lain mengenai pandemi Covid19.17

Pembelajaran daring sebagai satu-satu pilihan yang terbaik karena menerapkan protokol kesehatan, karena pembelajaran daring menggunakan jaringan internet dengan akses, konektif, fleksibel dan kemampuan untuk memunculkan berbagai jenis interaksi pembelajaran. ${ }^{18}$ Menurut Lily Ulfia dampak positif dapat dimaknai dari kondisi praktisi pendidikan melaksanakan kegiatan akademik dengan bekerja dari rumah (work from home).Betapaa tidak, praktisi pendidikan dibenturkan pada kondisi yang memaksa dan mengharuskan mereka menjadi mahir secara instan ${ }^{19}$

Para peserta didik yang pada umumnya adalah generasi milineal semakin bersenyawa dengan kemahiran mereka menyelesaikan kegiatan dan tugas belajar berbasis IT. Hikmah ini menjadi langkah tidak terencana dan di luar dugaan sebagai upaya pengembangan keterampilan dan pengetahuan setiap unsur praktisi pendidikan relevan dengan zaman. Selain dampak positif tersebut, terlihat pula dampak negatif pada keterbatasan praktisi pendidikan dalam tanggap kondisi, kesiapan personal membutuhkan pendampingan bahkan pedoman khusus untuk memahami IT sebagai jalur pilihan dalam bekerja. Celakanya, kemampuan dasar sangat beragam sehingga melahirkan respons yang tidak seragam dan potensial menciptakan kesenjangan pencapaian tujuan atau target pembelajaran.

Jadi pembelajaran daring selama masa pandemi Covid 19 sebagai pilihan yang tepat yang telah ditetapkan oleh pemerintah Indonsia demi keselamatan warga Negara Indonesia.

\section{E. Perkembangan kognitif anak usia 7-11 tahun}

Setiap manusia mengalami perkembangan hidup dalam berbagai dimensi, di antaranya perkembangan spiritual, emosi, kognitif, sosial dan moral. Salah satu perkembangan yang menjadi fokus perhatian dari seorang anak yaitu perkembangan kognitif. Penulis memilih usia ini berdasarkan teori yang ditemukan oleh Jean Pieget. Pieget berpendapat bahwa perubahan proses berpikir anak yang akan menghasilkan pertumbuhan dalam kemampuan untuk memperoleh dan menggunakan pengetahuan yang dimiliki, dan melihat perilaku berdasarkan kognitif. ${ }^{20}$ Persfektif kognitif yaitu melihat manusia berdasarkan cara berpikirnya. Itu sebabnya benih-benih kedisiplinan dan rasa tanggung jawab seharusnya sudah mulai ditumbuhkembangkan sejak dini, melalui latihan (habit Forming). ${ }^{21}$ Anak hendaknya diajar menyesuaikan diri, yang berarti dapat menerima dan mematuhi peraturan-peraturan mana yang dilarang.

\footnotetext{
17Wahyu Aji Dewi, Dampak Covid-19 Terhadap Implementasi Pembelajaran Daring Di Sekolah Dasar, Edukatif: Jurnal Ilmu Pendidikan Vol. 2 No. 1 April 2020, 55-61.

${ }^{18}$ Sister Buulolo, Nelci Kual, Rolan Marthin Sina dan Hendro H. Siburian, Pembelajaran Daring: Tantangan Pembentukan Karakter dan Spiritual Peserta Didik, Jurnal Pendidikan Kristen Vol. 1, no. 2, Desember 2020 (129-143).

${ }^{19}$ Lily Ulfia, Dinamika Pembelajaran Daring Pada Masa Pandemi Covid 2019 (Kendari: IAIN, 2020).

${ }^{20}$ Khiyarusoleh U., Jurnal, Kata Kunci: Konsep Dasar, Perkembangan Kognitif, Jean Pieget, Dialektika Jurusan PGSD, 2016

21Umar Tirtarahardja, S. L. La Sulo, Pengantar Pendidikan Kerja Sama Pusat Perbukuan Depdiknas dan Rineka Cipta, 2005, 11.
} 
ANALISIS TEOLOGIS TANGGUNG JAWAB ORANG TUA ... (Jonidius Illu, Dyulius Thomas Bilo, Yublina Kasse)

Pada umumnya faktor-faktor yang memengaruhi perkembangan kognitif yaitu: 1) kematangan fisik (biologis); 2) aktivitas-aktivitas anak memengaruhi perkembangan kognitif karena melalui aktivitas anak mengeksplorasi, mengamati dan mencoba anak berinteraksi dengan lingkungan. Contoh anak main ke bonbin; 3) pengalaman sosial anak belajar melalui interaksinya dengan orang lain. Waktu anak berinteraksi terjadi social transmission; 4) keseimbangan ketiganya penting supaya perkembangan kognitif dapat berjalan secara teratur. Ketiganya tidak bisa berdiri sendiri. ${ }^{22}$

Jadi menurut Jean Pieget anak usia 7-11 termasuk pada tahap kongkrit operasional yaitu anak bisa berpikir kongkrit, bisa berpikir konservasi, bisa membuat urutan, mengenal pengelompokan, dan mengenal seri.

\section{F. Pengaruh gadget pada pembelajaran daring terhadap perkembangan kognitif anak usia 7-11 tahun}

Dalam penggunaan gadget, ada dampak positif tetapi juga ada dampak negatif. Dari gambar di bawah ini adalah gambar tentang information processing theory atau penyimpanan informasi ke dalam memori. ${ }^{23}$

Maintenance Rehearsal

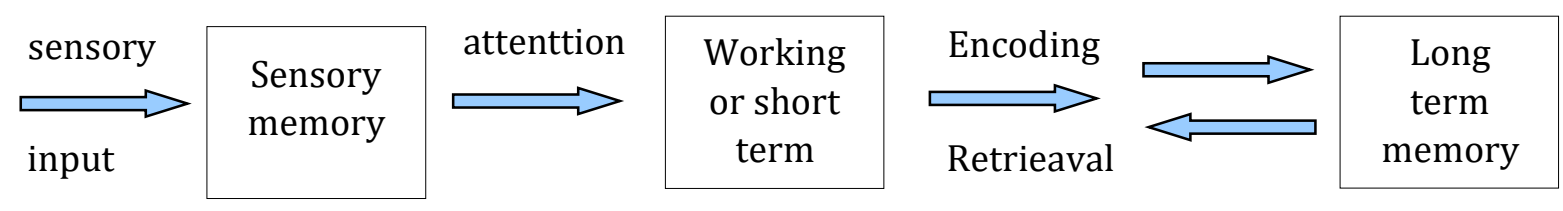

Gambar di atas, menjelaskan bahwa input masuk melalui sensory memory yang jika diberikan perhatian (attenttion) maka tersimpan dalam short term memory, yang jika diberi tanda (encoding) dan melakukan rehearsal, dengan mengulang-ngulang akan masukkan informasi ke long term memory.

Maknanya bagi perkembangan kognitif anak yaitu jika gadget digunakan dengan benar selama pembelajaran daring maka anak memiliki perkembangan kognitif yang sehat tetapi sebaliknya selama pembelajaran daring anak menggunakan gadget yang berlebihan bukan untuk pembelajaran daring maka perkembangan kognitif anak ke arah yang negatif yang berakibat pada kerusakan kognitif karena menyimpan informasi yang tidak berguna dalam memory.

Dari penjelasan di atas, dapat diberi beberapa kesimpulan antara lain:

1) Gadget memberi dampak bagi perkembangan kognitif, baik secara positif atau negatif;

2) Menggunakan kognitif pada hal yang benar memberi dampak positif terhadap bagi kehidupan anak. Pengetahuan adalah menyajikan realitas dalam pemikiran atau pengalaman sebagaimana realitas itu sesungguhnya di atas dasar-dasar yang cukup. Mengetahui sesuatu adalah berpikir atau

22Imam Hanafi Eko Adi Sumitro, Perkembangan Kognitif Menurut Jean Piaget dan Implikasinya Dalam Pembelajaran, ALPEN: Jurnal Pendidikan Dasar Vol. 3 No. 2, Juli - Desember 2019, 87.

23Paul D. Meier, dkk., Pengantar Psikologi dan Konseling Kristen 1, terj. Johny The (Yogyakarta: ANDI, 2009), 133-138. 
mengalaminya sebagaimana hal itu sesungguhnya atas dasar yang teguh seperti bukti, pengalaman, kata hati, dan lain sebagainya. ${ }^{24}$

3) Seorang anak yang bertumbuh dan bersemangat adalah seorang yang menghargai kehidupan intelektualnya dan bekerja mengembangkan akal budinya dengan kehati-hatian. ${ }^{25}$

\section{G. Analisis Teologis tanggung jawab orang tua Kristen dalam pendampingan pembelajaran daring}

Anak merupakan bagian dari keluarga. Penting diketahui bahwa keluarga adalah 'institusi pertama yang didirikan Allah, bukan gereja, bukan sekolah, dan lembaga atau istitusi lainnya (Kej. 2:18-25). ${ }^{26}$ Keluarga Kristen di dunia merupakan pusat dan tujuan dari perjanjian Allah (as the center of Gods covenant purpose). Perhatikan penetapan Allah pada Kejadian 12:3, di mana melalui berkat Allah kepada Abraham sekeluarga, seluruh bumi diberkati Keluarga Kristen di dunia merupakan miniatur keluarga Allah di dalam kekekalan. Keberhasilan dalam membangun keluarga Kristen yang benar, pada saat yang sama merupakan kesaksian akan keluarga Allah.

Yongki Karman berkata, "keluarga adalah tempat terbaik untuk membentuk integritas pribadi. Keluarga adalah sekolah kewajiban yang dibangun di atas kasih. Keluarga adalah tempat ketulusan diuji ketika ada yang berbuat salah harus mengaku salah dan meminta maaf. Keluarga adalah tempat berteduh kala badai kehidupan mengamuk. Keluarga saleh harus dimulai dari diri sendiri. Komitmen dan konsistensi kita. Keseriusan menginvestasikan waktu. Keluarga adalah gerbang pertama orang menyatakan lulus ujian kesalehan. ${ }^{27}$ Sebaliknya, jika gagal membangun keluarga, maka sebagai anak-anak Allah, juga gagal menunjukkan keindahan keluarga Allah. Itu sebabnya, keluarga menjadi sasaran pekerjaan Iblis yang tujuan utamanya adalah merusak keluarga, sehingga di dalam anugerah Allah orang tua wajib melakukan yang terbaik dalam membangun keluarga yang berkenan kepada-Nya. John Piper berkata, "anak-anak mengalami kekuatan, kepemimpinan, perlindungan, keadilan dan kasih dari ayah mereka; dan mereka mengalami perhatian, mereka mengalami perhatian, pemeliharaan, kehangatan, keintiman, keadilan, dan kasih dari ibu mereka dan tentu saja semua ini saling melengkapi." 28

Selain itu, Erastus Sabdono juga berkata, "orang tua harus menyadari bahwa anakanak mereka adalah milik Tuhan. Orang tua bertanggung jawab kepada Tuhan dalam membesarkan anak-anak dan masa depan mereka setelah orang tua meninggal. Oleh sebab itu orang tua harus mengerti dengan benar bagaimana memperlakukan anakanak sesuai dengan kehendak Tuhan sebab mereka adalah anak-anak panah Tuhan dan harus menjadi anak-anak panah yang efektif bagi Tuhan. ${ }^{29}$

Dari penjelasan Karman dan Sabdono, dapat disimpulkan bahwa keluarga sebagai tempat yang utama bagi seorang anak membentuk nilai kehidupan yang berguna dalam

\footnotetext{
${ }^{24}$ J. P. Moreland, Kasihilah Allahmu Dengan Segenap Akal Budimu, terj. Linda Indriani S. (Surabaya: Momentum, 2021), 50-67.

${ }^{25}$ Moreland, Kasihilah Allahmu Dengan Segenap Akal Budimu, 67.

${ }^{26}$ Stevri Indra Lumintang dan Danik Astuti Lumintang, Theologi Pernikahan Kristen di Tengan Krisis (Jakarta: Geneva Insani Indonesia, 2016), 76-77.

${ }^{27}$ Yongki Karman, Kata dan Karya: Refleksi-refleksi tentang Tuhan-Manusia, Gereja, dan Masyarakat (Jakarta: Perkantas, 2017), 213.

28John Piper, This Momentary Marriage, terj. Yakob Riskihadi (Bandung: Pionir Jaya, 2012), 159.

${ }^{29}$ Erastus Sabdono, Mengupas Hal Warisan (Jakarta: Rehobot Literatur, 2015), 13.
} 
ANALISIS TEOLOGIS TANGGUNG JAWAB ORANG TUA ... (Jonidius Illu, Dyulius Thomas Bilo, Yublina Kasse)

hidupnya sehingga menjadi pribadi yang utuh dan anak menjadi pribadi yang memuliakan Kristus.

Salah satu pertanyaan untuk para orang tua yaitu bagaimana orang tua menilai kehadiran seorang anak? Alkitab menyatakan bahwa anak adalah mahkota. Mahkota orang tua adalah anak cucu (Ams. 17:6). Ini menunjukkan bahwa anak-anak yang merupakan karunia Allah, yang dipertanggungjawabkan kepada Allah, yang mengaruniakan anak-anak tersebut. ${ }^{30}$ Ditambahkan juga oleh Jimmy Pardede ${ }^{31}$ bahwa, "Ketika Tuhan mempercayakan anak, ini adalah tugas yang Tuhan bebankan dan percayakan dengan sangat indah dan limpah, namun penuh tanggung jawab."

Alkitab memberi tempat yang penting untuk anak-anak. Karena itu, Alkitab PL dan PB, banyak berbicara tentang anak-anak. Dalam PL, anak-anak sebagai bagian dari Perjanjian Allah (Kej. 1:28; Ul.4:9-10; 6: 7-9; Yos. 24:15), anak-anak merupakan pernyataan berkat Allah (Mzm. 127:3-5; bndk. 1 Sam. 1:10-11). ${ }^{32}$ Dalam PB, perlu untuk memperhatikan sikap Yesus terhadap anak-anak. Menurut Tuhan Yesus, anak kecil adalah model untuk menerima Kerajaan Surga (Mat. 18:1-4). Tuhan Yesus merindukan kehadiran anak-anak (yang dianggap pengganggu) dan memberkati mereka (Mark. 10:13-16) dan menyembuhkan mereka (Luk. 9:37-43). Peringatan Tuhan Yesus yang sangat keras berhubungan dengan anak-anak dalam Matius 18:6, bahwa Yesus Kristus peduli kepada anak-anak yang telah beriman kepada-Nya, sehingga tidak diizinkan untuk menggoda anak-anak tersebut agar jatuh dalam dosa ${ }^{33}$, sebagaimana PL, dan PB menegaskan bahwa anak-anak adalah bagian dari perjanjian Allah (Kis. 2:39) serta PL, dan PB juga menjadikan kehadiran anak sebagai salah satu tanda berkat Allah (Luk. 1:7, 25).

Dari Allah, orang tua menerima anak-anak, dan kepada Allah orang tua mengarahkan anak-anak itu. Kehadiran anak dalam hidup pernikahan sungguh merupakan anugerah dan berkat Allah, sehingga orang tua berkewajiban untuk memuridkan anak sebagai murid Yesus (Mark. 10:13-14, Kej. 1:28, Mzm. 127:3-5). Dalam Efesus 6:1-4 dijelaskan bahwa: a) Ayah mempunyai tanggung jawab sebagai pemimpin untuk membesarkan anak-anak dalam ajaran dan nasihat Tuhan; b) Ibu dan ayah mempunyai tanggung jawab dalam pernikahan untuk membesarkan anak-anak di dalam Tuhan dan ayah mempunyai tanggung jawab sebagai pemimpin; c) Ayah dan ibu mempunyai satu sasaran, yaitu anak itu harus dibesarkan dalam 'ajaran dan nasihat Tuhan. (jangan biarkan anak mengadu domba orang tua tetapi orang tua harus sehati); c) Menunjukkan Allah kepada anak-anak. Anak-anak mengalami kekuatan, kepemimpinan, perlindungan, keadilan dan kasih dari ayah dan anak-anak mengalami perhatian, pemeliharaan, kehangatan, keintiman, keadilan dan kasih dari ibu; d) Allah menugaskan ayah dan ibu untuk membesarkan anak-anak sehingga anak-anak bertumbuh menjadi besar dengan melihat Kristus mengasihi gereja dan melihat gereja senang mengikuti Kristus. Banyak energi yang dibutuhkan untuk membentuk anak-anak unggul bagi Kristus. ${ }^{34}$ Anak sebagai berkat Allah maka sikap orang tua, yaitu kehadiran anak membuat orang tua lebih efesien mengatur uang dan waktu, bekerja lebih keras dan bertanggung jawab terhadap tingkah laku anak, kehadiran anak, orang tua belajar

30Mangapul Sagala, Rahasia Hidup Bahagia (Jakarta: Perkantas, 2018), 45.

31Jimmy Pardede, Hikmat Bagi Peran Ayah dan Ibu, 172.

${ }^{32}$ Nicholas P. Wolterstorff, Mendidik Untuk Kehidupan, terj. Lina Asali (Surabaya: Momentum, 2010), 284.

${ }^{33}$ Matthew Henry, Tafsiran Matthew Henry - Injil Matius 15-28 (Surabaya: Momentum dan Oikonomos, 2008), 879-880.

${ }^{34}$ Jonathan A. Trisna, Two Becoma One Membangun dan Mewujudkan Pernikahan Bahagia Sesuai Prinsip Alkitabiah(Yogyakarta: ANDI, 2017), 268. 
untuk merendahkan hati di hadapan Allah dalam mendidik karena tanpa bantuan Allah sulit sekali mendidik anak di jalan yang benar. Kekayaan, kedudukan, kekuasaan tidak dapat menjadi kunci sukses dalam mendidik anak. Orang tua dapat memantau sehingga anak tidak menjadi liar misalnya mendapatkan informasi yang menyesatkan, kriminal, pornografi atau informasi apa saja yang negatif.

Tanggung jawab orang tua mendidik anak terdapat dalam Ulangan 4:9-10, Ulangan 6:4-9, Amsal 3:11-12, Amsal 19:18, Amsal 22:6, Amsal 22:15, karena anak merupakan berkat Allah maka orang tua harus memelihara, merawat berkat Allah ini dengan penuh tanggung jawab, artinya orang tua bersedia menyediakan waktu, menyediakan diri, hati, dan kepentingan lain demi anak.

Kesalahan orang tua yaitu dengan mengantikan kehadiran mereka dalam hidup anak anaknya melalui hal hal yang bersifat materi atau benda, memanjakan dengan berbagai fasilitas yang diangap dapat menggantikan nilai kehadiran dan pembimbingan mereka dengan memberikan berbagai jenis barang yang mereka anggap kebutuhan anak. Dibanjiri dengan bertumpuk-tumpuk mainan, pakaian, perhiasan, dan apa saja yang diinginkan anak, bahkan anak dibiarkan memilih dan melakukan apa saja yang mereka mau, serta tidak mendidik anak dengan disiplin.

Jadi dapat disimpulkan bahwa orang tua bertanggung jawab dalam mendidik anak sehingga dalam hal penggunaan gadget selama pembelajaran daring dapat digunakan dengan benar sehingga seumur hidup anak berjalan dalam jalan yang benar dengan bersikap memberi perhatian atau kasih sayang yang cukup

Beberapa tanggung jawab orang tua selama pembelajaran daring yaitu:

1. Memberikan dorongan kepada anak agar terus mengikuti pendidikan

Pendidikan dalam Bahasa Inggris adalah educatian, berasal dari Bahasa Latin educare, di mana $e$ adalah keluar dan ducare adalah pemimpin. Jadi pendidikan adalah memimpin keluar. Analogi gua dari Plato - bayangan vs riil dan asli, mendidik (pikirannya terbuka)/memimpin keluar dari gelap kepada terang. Jadi pendidikan adalah memimpin keluar orang-orang dari pikirannya yang tidak riil atau gelap/bayangan dengan tujuan orang-orang ini menjadi mengerti dunia yang riil atau terang, yaitu berhubungan dengan dunia yang riil. ${ }^{35}$ Menurut Ferry Yang, pendidikan ini dimulai dari rumah supaya terbentuk karakter yang benar ${ }^{36}$. Pendapat ini ditegaskan juga oleh Junihot Simanjuntak ${ }^{37}$ bahwa, "setelah mengikuti kegiatan belajar, peserta didik kita juga mengalami perubahan sikap, dari negatif ke positif, dari tidak bisa melakukan sesuatu, menjadi terampil atau andal."

Amsal 29:17, didiklah anakmu, maka ia akan memberikan ketentraman kepadamu, dan mendatangkan sukacita kepadamu. Setelah menyadari bahwa anak adalah suatu kepercayaan yang Allah berikan dan dituntut tanggung jawab dari padanya, maka orang tua mendidik anak dan membesarkannya di dalam iman. Selain itu orang tua jika tidak memberikan kesaksian yang tepat maka anak gagal melihat citra Allah di dalam dirinya. ${ }^{38}$ Dalam dunia post-

${ }^{35}$ Ferry Yang, Pendidikan Kristen (Surabaya: Momentum, 2018), 3-4.

${ }^{36}$ Yang, Pendidikan Kristen, 140

${ }^{37} J u n i h o t$ Simanjuntak, Ilmu Belajar dan Didaktika Pendidikan Kristen (Yogyakarta: ANDI, 2021), 37.

${ }^{38}$ Menurut Sabdono, orangtua juga harus juga dapat diteladani oleh anak-anak mereka, dari hal-hal sederhana seperti cara berpakaian, pola makan, cara bergaul, irama kerja, penggunaan uang, memperlakukan orang lain, menjaga kesehatan, etos bekerja, dalam memenuhi janji, kehidupan iman dan lain sebagainya. Orangtua yang tidak menjadi teladan adalah orangtua yang tidak menghormati diri 
ANALISIS TEOLOGIS TANGGUNG JAWAB ORANG TUA ... (Jonidius Illu, Dyulius Thomas Bilo, Yublina Kasse)

modern, telah terjadi banyak perubahan sehingga sebagai orang tua perlu mempersiapkan anak untuk menghadapi perubahan tersebut, selain itu orang tua bertanggung jawab memperlengkapi anak melalui pendidikan nonformal. Salah satu cara untuk mengatasi kebodohan adalah melalui pendidikan. Menurut Harianto ${ }^{39}$, pendidikan di rumah maupun di sekolah perlu memiliki struktur dan disiplin yang cukup untuk membentuk pola-pola tingkah laku anak karena salah satu tujuan pendidikan yang terpenting adalah mempersiapkan anak-anak untuk kehidupan, karena membentuk nilai-nilai kehidupan. Masa pendidikan terpenting adalah masa kanak-kanak, kepentingannya menyangkut beberapa prinsip, antara lain: disiplin, yaitu secara konsisten mendidik anak untuk disiplin dalam mulai dari hal-hal yang kecil, contoh: membuang sampah pada tempatnya ${ }^{40}$

2. Mendorong anak agar disiplin dalam belajar. Dalam kesibukan kedua orang tua, sering timbul pertanyaan tentang siapa yang bertanggung jawab dalam masalah disiplin anak. Konsentrasi yang terbagi-bagi antara pekerjaan, pelayanan, kegiatan sosial dan kehidupan rumah tangga telah membuat banyak orang tua merasa tidak mempunyai waktu untuk memikirkan tentang disiplin anak. Mengapa anak-anak Anda tidak disiplin, sulit ditertibkan, suka membantah, atau melawan perintah, mereka mempunyai kebiasaan buruk, melawan otoritas, tidak menghargai orang yang lebih tua dan kurang bertanggung jawab, mereka tidak mempunyai sopan santun, melawan pendapat orang tua dan guru, atau nasihat atau wejangan Anda? Jika anak tidak disiplin maka anak akan bertumbuh dan berkembang menjadi anakanak yang tidak memiliki disiplin hidup. Mengapa anak-anak berkelakuan buruk? Sikap, perilaku, perangai atau keteladanan Anda sebagai orang tua atau pemimpin keluarga buruk, sehingga anak-anak Anda meragukan kapasitas dan kapabilitas Anda sebagai pemimpin keluarga yang patut dihormati Anda membiarkan permusuhan, perseteruan atau percecokan berlangsung di tengah-tengah keluarga Anda tanpa solusi Anda menolerir, memperbolehkan atau membiarkan pergaulan 'serba boleh terhadap anakanak Anda sehingga mereka bebas melakukan 'apa saja tanpa memahami apakah perilaku mereka benar atau salah.

3. Berikut kesalahan orang tua dalam melakukan pendampingan pembelajaran daring antara lain:

a. Orang tua memberikan toleransi berlebihan kepada anak-anak sehingga mereka cenderung selalu melanggar kesepakatan untuk mendapatkan ruang toleransi yang lebih luas lagi.

b. Orang tua menerapkan pendidikan dan pengajaran yang buruk dan tidak bermutu kepada anak-anak sehingga mereka mendapatkan pendidikan dan pengajaran yang rendah dan kacau.

c. Orang tua pilih kasih terhadap anak-anak sehingga menimbulkan permusuhan, perseturuan, iri hati, cemburu, dan dendam di antara mereka dan juga terhadap orang tua.

sendiri, mereka tidak bisa atau tidak patut untuk dihormati pula. Apa yang dilihat anak sejak kecil dari orangtua membentu kepribadian dan diri anak tersebut yaitu seluruh pola hidup, pola piker dan semua filosifinya. Sabdono, Mengupas Hal Warisan, 51-52.

${ }^{39}$ Harianto, Teologi PAK Metode dan Penerapan Pendidikan Agama Kristen dalam Alkitab (Yogyakarta: ANDI, 2021), 2.

${ }^{40}$ Daniel Ronda, Pengantar Konseling Pastoral (Bandung: Kalam Hidup, 2015), 133-135. 
d. Orang tua membiarkan intrik-intrik berkembang di tengah-tengah keluarga sehingga menimbulkan permusuhan di dalam keluarga.

e. Adanya ketidakadilan yang dirasakan oleh anak-anak karena sikap dan tindakan diskriminatif, misalnya orang tua boleh melakukan, tetapi anak-anak tidak boleh, tanpa disertai penjelasan yang rasional.

f. Adanya perbedaan pendapat yang tajam di tengah-tengah keluarga, misalnya orang tua dengan anak-anak atau anak-anak dengan anakanak namun tidak bisa diselesaikan dengan damai.

g. Orang tua menerapkan pola asuh yang buruk terhadap anak-anak sehingga mereka terjerumus melakukan perbuatan atau tindakan yang melawan hukum.

Disiplin perlu ditegakkan atau terapkan kepada anak-anak sejak mereka masih berusia dini. Keterlambatan atau kesalahan penerapan disiplin pada usia dini akan mengakibatkan orang tua mengalami kesulitan besar dikemudian hari. Jika orang tua lemah dan ragu-ragu menegakkan disiplin, maka orang tua menjadi objek permainan anak-anak sehingga secara tidak langsung turut mendorong anak-anak menuju jurang kehancuran. Sebaliknya, jikalau orang tua tegas dan berani, maka anak-anak menghormati kedaulatan orang tuanya. Selain itu ketegasan menuntun anak-anak agar tertib dan melewati jalan yang benar menuju masa depan yang lebih baik. Unsur yang paling penting dalam mengasuh anak-anak adalah 'kasih sayang dan kendali. Artinya 'kasih saya tanpa kendali menghasilkan sikap tidak hormat atau anak-anak tidak mampu menghargai orang tua. Sebaliknya, pengasuhan 'kendali tanpa kasih sayang, maka cenderung bertindak otoriter terhadap anak-anak. ${ }^{41}$

Beberapa metode mendisiplinkan anak: a) Otoriter: menekankan ketaatan yang optimal dengan peraturan-peraturan tanpa memperhatikan keunikan; b) Demokrasi: memberi kebebasan sebagai cara untuk memberi kesempatan kepada anak untuk mengembangkan diri, namun kesalahannya adalah memberi toleransi yang berlebihan sehingga bisa melanggar norma-norma; c) Permisif: memberi kebebasan kepada anak karena menganggap setiap anak mempunyai tendensi alamiah untuk mengerti kemampuan dirinya sendiri tanpa pengontrolan; d) Konsistensi: secara konsisten mengajarkan anak, dan memberi teladan sehingga anak tidak mengalami ambivalen.

Cara mendisiplinkan anak dengan baik yaitu: a) orang tua konsisten dan bijaksana. Antara ayah dan ibu ada kesepakatan, jangan sampai apa yang dilarang oleh ayah, diamdiam diberikan oleh ibu. b) Standar yang orang tua pakai untuk disiplin anak sederhana dan jelas, misalnya memberikan kesempatan kepada anak nonton TV sambil makan, minggu berikutnya tidak memberikan kesempatan untuk makan sambil menonton TV42; c) Disiplin pada saat yang tepat. Banyak orang tua yang mendisiplin anak setelah frustrasi karena kesalahan yang bertumpuk-tumpuk dari anak sehingga anak seringkali tidak mengerti dengan pasti ia didisiplinkan bahkan dihukum karena apa.

Jadi orang tua bertanggung jawab dalam memberi pendampingan selama pembelajaran daring agar anak mengikuti pendidikan dengan baik sehingga tidak terjadi penyalahgunaan gadget yang berdampak buruk bagi perkembangan kognitif.

\footnotetext{
${ }^{41}$ Ayang Emiyati, Mendisiplinkan Anak Menurut Prinsip Kristen, Evangelikal: Jurnal Teologi Injili dan Pembinaan Warga Jemaat, vol. 2 No. 2, Juli 2018, 147-156.

${ }^{42}$ Menurut Karman, jika anak dibiarkan saja berguru dari kotak ajaib yang bernama televisi. Perkataan kasar, kekerasan, atau adegan sadis dibiarkan menodai kemurnian anak. Kemurnian yang sekali hilang tak akan kembali lagi. Karman, Kata dan Karya, 212.
} 
ANALISIS TEOLOGIS TANGGUNG JAWAB ORANG TUA ... (Jonidius Illu, Dyulius Thomas Bilo, Yublina Kasse)

\section{Kesimpulan}

Anak adalah berkat Allah yang dipercayakan kepada orang tua untuk dididik pada jalan yang benar yaitu sesuai Alkitab. Orang tua memiliki peranan penting dalam mendamping selama pembelajaran daring agar anak fokus pada masa pendidikan yang berguna untuk masa depannya. Pada prinsipnya, gadget adalah seperangkat alat yang digunakan oleh manusia untuk memudahkan manusia dalam bekerja, belajar dan kegiatan lainnya. Penggunaan gadget yang benar selama pembelajaran daring berdampak pada perkembangan kognitif yang sehat, juga sebaliknya, jika penggunaan gadget yang salah maka merusak perkembangan kognitif anak usia 7-11 tahun. Anak pada usia ini diizinkan menggunakan gadget selama pembelajaran daring guna memudahkan pembelajaran dengan ketentuan atau aturan yang telah dijelaslan di atas dengan didamping oleh orang tua.

\section{Referensi}

Buulolo, Sister, Nelci Kual, Rolan Marthin Sina dan Hendro H. Siburian,Pembelajaran Daring: Tantangan Pembentukan Karakter dan Spiritual Peserta Didik, Jurnal Pendidikan Kristen Vol. 1, no. 2, Desember 2020 (129-143).

Dewi, Wahyu Aji, Dampak Covid-19 Terhadap Implementasi Pembelajaran Daring Di Sekolah Dasar, Edukatif: Jurnal Ilmu Pendidikan Vol. 2 No. 1 April 2020.

Emiyati, Ayang, Mendisiplinkan Anak Menurut Prinsip Kristen, Evangelikal: Jurnal Teologi Injili dan Pembinaan Warga Jemaat, vol. 2 No. 2, Juli 2018.

Gulo, Hiskia, Konsep Pencobaan Menurut Yakobus 1:12-15, Bonafide: Jurnal Teologi dan Pendidikan Kristen.

Harianto, Teologi PAK - Metode dan Penerapan Pendidikan Agama Kristen dalam Alkitab (Yogyakarta: ANDI, 2021).

Henry, Matthew, Tafsiran Matthew Henry - Injil Matius 15-28 (Surabaya: Momentum dan Oikonomos, 2008).

Illu, Jonidius, Pengusiran Setan: Sinkronisasi Iman, Kekudusan Hidup, Doa, dan Pengetahuan Alkitab, Phronesis: Jurnal Teologi dan Misi, vol. 2 No. 2, Desember 2020.

Karman, Yongki, Kata dan Karya - Refleksi-refleksi tentang Tuhan-Manusia, Gereja, dan Masyarakat (Jakarta: Perkantas, 2017).

Lumintang, Stevri Indra dan Danik Astuti Lumintang, Theologi Pernikahan Kristen di Tengan Krisis (Jakarta: Geneva Insani Indonesia, 2016).

Meier, Paul D., dkk., Pengantar Psikologi dan Konseling Kristen 1, penerj. Johny The (Yogyakarta: ANDI, 2009).

Moreland, J. P., Kasihilah Allahmu Dengan Segenap Akal Budimu, penerj. Linda Indriani S. (Surabaya: Momentum, 2021).

Mukhlisah A., Perkembangan Kognitif Jean Pieget dan Peningkatan Belajar Anak Diskalkulia," Pendidikan Islam, 2015.

Pardede, Jimmy, Hikmat Bagi Para Ayah dan Ibu (Surabaya: Momentum, 2021).

Piper, John, This Momentary Marriage, terj. Yakob Riskihadi (Bandung: Pionir Jaya, 2012).

Ronda, Daniel, Pengantar Konseling Pastoral (Bandung: Kalam Hidup, 2015).

Singgih D. Gunarsah dan Yulia Singgih Gunarsa, Psikologi Perkembangan Anak dan Remaja (Jakarta: Libri, 2011). 
Siahaan FB Wahyuni AS, Hubungan Lama Bermain Gadget Dengan Kondisi Mental Emosional Siswa Sekolah Dasar, Ilmu Kedokteran Makedonia Akses Terbuka (2019).

Indian Sunita, dan Eva Mayasari, Pengawasan Orang tua Terhadap Dampak Penggunaan Gadget Pada Anak, Jurnal Endurance 3 (3) Oktober 2018.

Sabdono, Erastus, Mengupas Hal Warisan (Jakarta: Rehobot Literatur, 2015).

Sagala, Mangapul, Rahasia Hidup Bahagia (Jakarta: Perkantas, 2018).

Simanjuntak, Junihot, Ilmu Belajar dan Didaktika Pendidikan Kristen (Yogyakarta: ANDI, 2021).

Sumitro, Imam Hanafi Eko Adi, Perkembangan Kognitif Menurut "Jean Piaget" dan Implikasinya Dalam Pembelajaran, ALPEN: Jurnal Pendidikan Dasar Vol. 3 No. 2, Juli - Desember 2019.

Surbekti, E. B., Parenting Anak-Anak (Jakarta: Gramedia, 2012).

Susabda, Yakub B., Pembinaan Keluarga Kristen (Bandung: Pionir Jaya, 2010).

Susabda, Yakub B. dkk., Pelayanan Konseling Melalui Telepon (Yogyakarta: ANDI, 2010).

Susilawati, Kadek Dwinita Viandari dan Kadek Pande Ary, Peran Pola Asuh Orang tua dan Penggunaan Gadget terhadap interaksi Sosial Anak Prasekolah, Jurnal Udayana, 2019.

Tirtarahardja, Umar, S. L. La Sulo, Pengantar Pendidikan Kerjasama Pusat Perbukuan Depdiknas dan Rineka Cipta, 2005.

Trisna, Jonathan A., Two Becoma One - Membangun dan Mewujudkan Pernikahan Bahagia Sesuai Prinsip Alkitabiah, cek. ke-5 (Yogyakarta: ANDI, 2017).

Ulfia, Lily, Dinamika Pembelajaran "Daring" Pada Masa Pandemi Covid 2019 (Kendari: IAIN, 2020).

U, Khiyarusoleh., Jurnal, Kata Kunci: Konsep Dasar, Perkembangan Kognitif, Jean Pieget, dialektika jurusan PGSD, 2016.

Wahidmurni, Pemaparan Metode Penelitian Kualitatif, Repositori Universitas Islam Negeri Maulana Malik Ibrahim (2017).

Wolterstorff, Nicholas P., Mendidik Untuk Kehidupan, terj. Lana Asali, cet. Ke-2 (Surabaya: Momentum, 2010).

Yang, Ferry, Pendidikan Kristen (Surabaya: Momentum, 2018). 